\section{ECONOMICS}

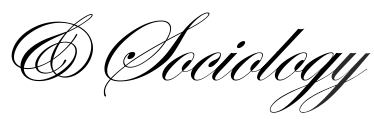

\title{
NEW LABELS, NEW ROLES? CHANGES IN PORTRAYING DISABLED PEOPLE IN THE POLISH PRESS
}

\author{
Olga Kurek-Ochmańska \\ University Information Technology \\ and Management in Rzeszow, \\ Poland \\ E-mail:okurek@,wsiz.rzeszow.pl \\ Monika Struck- \\ Peregończyk \\ University Information Technology \\ and Management in Rzeszow, \\ Poland \\ E-mail:mstruck@wsia.rzeszow.pl
}

\author{
Agata A. Lambrechts \\ University of York, \\ United Kingdom \\ E-mail:aal513@york.ac.uk.
}

Received: September, 2019

1st Revision: December, 2019

Accepted: March, 2020

DOI: $10.14254 / 2071-$

789X.2020/13-1/11

JEL Classification: Z13

\begin{abstract}
Changes in the perception of disabled people and the shift towards the social model of disability should also be reflected in the media debate. On the one hand, media expose the dominant social attitudes towards disabled people, on the other hand, they play an important role in shaping public opinion, influencing ways of thinking and talking about disability. The aim of the paper is to examine the extent to which the term osoba z niepetnosprawnosicia (person with a disability), which is seen in Poland as being connected to the social model of disability and the ideals of the UN Convention on the Rights of Persons with Disabilities, is used by the media and whether this is accompanied by changes in the presentation of social roles performed by disabled people. The analysis encompasses articles published in the selected Polish opinion-forming weekly magazines after ratifying the Convention (2012). The study shows that although the term osoba ₹ niepetnosprawnosicia is gradually gaining popularity, this is not related to the way disabled people and their social roles are presented.
\end{abstract}

Keywords: disabled people, people with disabilities, disability language, media, Polish press, social roles

\section{Introduction}

In recent years there has been a shift in defining disability: from so called "medical' model to "social model". Disability ceased to be understood as a mere medical condition and a problem of a particular person, which should be 'fixed' or changed in order for this person to be 'normal'. Social model of disability was developed in the 1970s by activists in the Union of the Physically Impaired Against Segregation (UPIAS), who, in the document Fundamental Principles of Disability, declared that "it is society which disables physically impaired people" (Oliver, 1996, p. 22). Disability is therefore treated as a form of social oppression, while impairment is seen as the limitation of a person's physical, mental or sensory function. It shifted 
the emphasis from "fixing" a disabled person to removing the disabling barriers and changing the society (Finkelstein, 1980, 1981; Barnes, 1991; Oliver, 1990, 1996; Shakespeare \& Watson, 2001).

Together with the wider adoption of the social model of disability, there have been also changes in the language used to describe disability and disabled people. The language used in public discourse has an educational function; it should change people's habits and show how to speak to avoid stigmatizing disabled people (Galasiński, 2013). In English, there are two widely used terms: "disabled people" and "people with disabilities". It must be noted, however, that the distinction between them is related not only to linguistics, but also to different ways of conceptualizing disability. The British disability activists tend to prefer the term "disabled people", explaining that these are people with impairments who are disabled by socially constructed barriers and that this term allows to acknowledge disability as a key part of people's experience. On the other hand, Americans prefer to use the term "people with disabilities", an example of "person-first language", in order to emphasise that a disability is just one of many characteristics of a person and does not define them (Lawson, 2001). As argued by Clark and Marsh (2002), in this way "disabilities" are confused with a person's medical condition, i.e. impairment, and disabling effect is placed within an individual and not in the society ${ }^{1}$.

In Poland the term that has recently gained a lot of recognition is osoba $z$ niepetnosprawnościa (person with a disability), which is considered by many to be the most appropriate, empowering, concentrating on a person and not on their disability. It is thought to be associated with the social model of disability and the ideas of the UN Convention on the Rights of Persons with Disabilities. It can be felt that this term has been used more and more frequently in public discourse over the last few years, however, there is a lack of research in this area.

Two main questions formed the basis for this study:

a) Does this "change of label" allow disabled people to gain a new identity of "people with disabilities", which enables them to play social roles unavailable to them so far?

b) Are these changes reflected in the media debate?

The aim of the article is to examine the extent to which the term osoba $z$ niepetnosprawnościa is used in the Polish opinion-forming press and whether it is accompanied by changes in the presentation of social roles performed by disabled people. The research was conducted using media content analysis of four Polish weekly magazines: "Newsweek", "Polityka", "Tygodnik Powszechny" and "Wprost". The first part of the paper describes briefly the main issues connected to the disability language in Poland, highlighting the controversies around the use of the term osoba $z$ niepetnosprawnosicia. The second part of the paper highlights the role of media in creating the image of disabled people and refers to the examples of research in this area. The explanation and description of the research methods used in the paper forms the third part of the article, while the final part contains the description of the main results of the research.

\section{Language of disability in Poland}

Disability language in Poland has undergone a lot of changes. While terms like kaleka (a cripple), upośledzony (handicapped), inwalida (an invalid) have been regarded as pejorative and have been gradually falling into disuse, the widely used term osoby niepetnosprawne (disabled people) has also been questioned as suggesting that disability is all-encompassing and

\footnotetext{
${ }^{1}$ As the Authors of the paper are in favour of the British approach, the term "disabled person/people" will be used throughout the paper.
} 
defines their entire existence. There were attempts to use expressions like osoby z ograniczona sprawnościa (people with limited ability) (Brzezińska,Woźniak \& Maj, 2007), osoby z niepetna sprawnościa (people with partial ability) (Dycht \& Marszałek, 2009; Pawlas-Czyż, 2012), they have not, however, become widespread.

Nowadays there is more and more tendency to use the term osoba $z$ niepetnosprawnościa (person with a disability) as a more neutral and "people-first" term. A famous Polish linguist, Jerzy Bralczyk, claimed in 2006 that this expression might appear in Polish language but would not be used (Białek, 2006). In a Bill on giving equal opportunities to people with disabilities drafted in 2008, the term osoba z niepetnosprawnościa was introduced to adapt the language to the one used in Convention on the Rights of Persons with Disabilities (translated into Polish, however, as Konwencja o prawach osób niepetnosprawnych (Convention on the Rights of Disabled People) ${ }^{2}$. D. Galasiński claimed in 2013 that "nobody speaks like that", i.e. uses the term (Galasiński 2013, p. 5). It seems he referred more to everyday life as the term did appear in academic publications (Rutkowska, 2007; Janocha, 2008; Franczak, 2011; Tomczyszyn \& Romanowicz, 2012; Paszkowicz \& Garbat, 2013; Bąba, 2015; Garbat, 2015; Goldman and Wojtaś 2015; Kubicki, 2017; Korombel, 2018; SztobrynGiercuszkiewicz, 2018) as well as publications of The Office of the Commissioner for Human Rights (RPO 2012; Kurowski, 2014; RPO 2015). In 201751 Polish NGOs signed an open letter to journalists with the appeal to create socially sensitive public discourse by using appropriate language to describe disabled people. One of the demands was to use the term osoba $z$ niepetnosprawnościa as it is in accordance to the UN Convention and concentrates the attention on a person, not on their disability.

The supporters of replacing the term osoba niepetnosprawna with osoba $z$ niepetnosprawnościa claim that the latter emphasises the complexity of the individual's identity, indicates their subjectivity and suggests that disability is just one of the many characteristics of the person (Kaczmarska, 2017). Moreover, the shift in terminology may lead to psychological change in the way disabled people perceive themselves, and may result in removing the stigma (Fiedorowicz, 2016). In addition, as suggested by Mikołajczyk (2012), the term osoba $z$ niepetnosprawnościa is wider than the term osoba niepetnosprawna and encompasses also some elderly people and people whose disability is not visible or self-evident. This term is also used by many NGOs representing disabled people (Kurowski, 2014).

However, the opponents of the use of this term argue that such a prepositional phrase is foreign to the Polish language (Białek, 2006). However, as Galasiński points out, „Language is not owned by linguists and the decision how the users of this language write or speak should not be made by linguists" (Galasiński, 2013, p. 3) as language is constantly changing and adjusting to social and political contexts. The use of the term osoba z niepetnosprawnościa is perceived by some as impractical (Sieradzki, 1997), irrational and as an example of unnecessary political correctness (Fiedorowicz, 2016). Galasiński (2013), even though he agrees that this term might be cumbersome to use in everyday life, claims that it should be used in public discourse (especially in legal documents) and this way it will be disseminated, especially if it starts to be used by the elites. Rymsza (2016) argues that the difference between English "disabled person" and "person with disabilities" carries a different meaning than in case of their Polish equivalents as the term niepetnosprawnośc implies the loss of ability is partial and the equivalent of "disability" should be niesprawność. Moreover, the noun niepetnosprawność is uncountable in Polish, which leads to the confusion whether to translate "with disabilities" as $z$ niepetnosprawnościa or $z$ niepetnosprawnościami. He opts therefore for the use of the term

\footnotetext{
${ }^{2}$ http://www.niepelnosprawni.pl/ledge/x/25311
} 
osoba niepetnosprawna as the most accurate, complying with the basic rules of Polish language and having the highest 'humanistic factor'.

\section{Disability in the media}

The statement that mass media have an influence on shaping attitudes and opinions is now a truism. From the moment of commercialization of the press in the second half of the 19th century, through the appearance of cinema and radio broadcasting to the development of television and the appearance of the Internet, researchers have differently assessed the degree of social and cultural impact of mass media on their recipients.

In the 1930s and 1940s, social behaviourists developed the "magic bullet" or "hypodermic needle theory", which emphasized the all-powerful media power over atomized mass society. This theory was based on the observation of incredible effectiveness of propaganda, e.g. in the German Third Reich (Sproule, 1987, p. 60). For the first time it was invalidated by Paul Lazarsfeld and Hert Herzog in the 1940s (Lazarsfeld, Berelson \& Gaudet, 1948). Since then a model of the diverse influence of mass media on diverse and heterogeneous mass audience began to be popular (Kozłowska, 2006, p. 57). It emphasised the impact of a complex human personality on the assimilation of media information and thus the limited persuasive possibilities of the media itself. In the 1950s, Elihu Katz and Paul Lazarsfeld in the book "Personal Influence: The Part Played by People in the Flow of Mass Communications" disposed of the theory of omnipotent media and presented the theory of a two-step flow of communication (Katz \& Lazarsfeld, 1955; Katz, 1957), which is explained below in the methodological part of this paper.

Shortly afterwards, in the 1960s, Joseph Klapper presented Phenomenistic Theory (also referred as Reinforcement or Limited Effects Theory), according to which the mass media have an indirect and not immediate impact on the recipient, through a gradual but systematic and uniform transmission of certain messages (problems, situations). The recipients slowly assimilate these messages, begin to understand, interpret and form them or modify their beliefs, opinions and attitudes. Finally, those minor, individual changes accumulate and emerge in the form of significant changes in a given topic (Klapper, 1957; McQuail, 2010; Simson, 2012; Goban-Klas, 2008).

According to this theory, if disabled people were consistently portrayed by the media as professionally and socially active, instead of being presented as passive, helpless and dependent, it is highly probable that the recipients would begin to perceive them in this way. However, mass media tend to treat disability very superficially, repeating and strengthening the existing stereotypes. Barnes (1992) distinguished the main types of the recurring media stereotypes: the disabled person as pitiable and pathetic, as an object of violence, as sinister and evil, as atmosphere or curio, as super cripple, as an object of ridicule, as their own worst and only enemy, as burden, as sexually abnormal, as incapable of participating fully in community life. John Clogston in his study of major U.S. newspapers (1990) defined five media models of disability representation: three "traditional" (stigmatising) categories, which include the Medical Model (disability as an illness or malfunction), the Social Pathology Model (disabled people as disadvantaged) and the Supercrip Model (disabled people as deviant because of "superhuman" feats), and two "progressive" (empowering) categories, including the Minority/Civil Rights Model (disabled people as members of the disability community) and the Cultural Pluralism Model (disabled people presented as non-disabled people would be). Haller in her content analysis of the media coverage of the Americans with Disabilities Act (1999) added three more models: two progressive ones: the Legal Model (disabled people presented as having legal rights) and Consumer Model (disabled people as an untapped consumer group) 
and one traditional model: Business Model (disabled people and their issues presented as costly to society and businesses especially).

Polish research on the image of disabled people in the media indicates that the "pity/heroism dichotomy" (Inimah, Mukulu \& Mathooko, 2012) is still present. Disabled people are most often portrayed either as unfortunate, dependent, requiring the help of others ("victims") or tragic heroes who perform unusual acts "despite" their disability ("supercripples") (Ruść, 2007; Rozmus, 2012; Niedbalski, 2015, Struck-Peregończyk \& LeonowiczBukała, 2018). The reason for the popularity of these simplified ways of presenting disabled people may be associated with the economic criteria of raising viewership, which seem to be more important than a sense of mission, and emotional and sensational stories tend to attract mass viewers (Rozmus, 2012). However, Struck-Peregończyk \& Kurek-Ochmańska (2018) in their study of the image of disabled people in "Polityka" weekly magazine between 1997 and 2017 noticed a gradual increase in the number of articles dominated by progressive models and a simultaneous decrease in the number of articles with dominant traditional models.

In terms of language use, the analysis of the image of disabled people in two most-read Polish newspapers - "Fakt" and "Gazeta Wyborcza" by Struck-Peregończyk \& LeonowiczBukała (2018) showed that there were still examples of the use of stigmatising, outdated terms like kaleka (a cripple), upośledzony (handicapped), inwalida (an invalid), as well as emotive expressions emphasising limitations, dependency and tragic fate of disabled people. However, there is still a noticeable change in the language used to describe disability and disabled people between 1997 and 2017 - from articles filled with pejorative terms and expressions to neutral and non-stigmatizing language (Struck-Peregończyk \& Kurek-Ochmańska, 2018).

\section{Methodological approach}

In regards to the changes of perception of disability, the main purpose of this study was to investigate whether the expression osoba $z$ niepetnosprawnościq is used in the media discourse. Another goal was to examine if any changes of the way disabled people are presented concerning social roles can be observed. As the research problem defined above is broad, the following questions were asked at the conceptual phase of the research:

1. How often is the subject of disability and disabled people presented in the Polish opinion-forming press? Is the frequency affected by the political bias of the magazine? Do socio-political events influence this frequency?

2. What is the subject matter of the articles on disability issues in the Polish opinionforming press?

3. Is the subject of disability issues prominently displayed or marginalised in the Polish opinion-forming press? How often is it a cover story? How much space is dedicated to it (extensive reportages or short paragraphs)? What is the placement of the articles? Are there any journalists specializing in the subject?

4. What kind of language is used to describe disability and disabled people in the Polish opinion-forming press? Is it different for different people - journalists and 'sources'(disabled people, their family, experts)? Is the language used intentionally? Is there an increasing tendency for using the phrase osoba z niepetnosprawnościa (person with a disability)? Is there any noticeable evolution of this terminology over time? Is there any noticeable difference in the terminology used by different magazines due to their political bias?

5. Have the social roles played by disabled people changed? If yes, how? Is there any correlation between this change and the shift in the language used to talk about disability issues? 
The first phase of the research was a pilot study. In order to determine the number of articles related to disability issues the electronic archive of "Polityka" weekly magazine was searched using the following keywords: osoba niepetnosprawna (a disabled person), osoba $z$ niepetnosprawnościa (a person with a disability), niepetnosprawny (disabled (a noun), all of them in various grammatical forms. The search encompassed the period between September 2012 and December 2018. The search exposed unexpectedly high number of disability-related stories and the growing tendency to use the term osoba $z$ niepetnosprawnościa. The findings formed the basis for the following research hypotheses:

1. There are changes in the way disability and disabled people are presented by the Polish opinion-forming press. Over time, the frequency of using the phrase osoba $z$ niepetnosprawnościq increases.

2. There are changes in the way social roles taken by disabled people are presented in the Polish opinion-forming press. Over time, the number of articles in which disabled people are presented as passive decreases and the number of articles in which they are presented as active in social and professional life increases.

The ambiguous concepts of an "active" and "passive" disable person used in the hypotheses were defined as:

- a passive disabled person - a person in need of help, unable to function independently, professionally inactive, uncommitted, helpless, etc.

Indicators: the presentation of a disabled person through their physical limitations or illness and from the angle of social and economic barriers.

- an active disabled person - independent, professionally active, socially open, an engaged citizen, performing various social roles (e.g. employee, parent, partner, social worker, athlete, pupil, etc.), entrepreneurial, a go-getter, etc.

Indicators: disabled people presented in diverse social roles.

Content analysis of media was selected as a research method in order to answer research questions and verify hypotheses. Out of a dozen socio-political opinion-forming weekly magazines, we decided to analyse the following titles (alphabetically): "Newsweek"3,

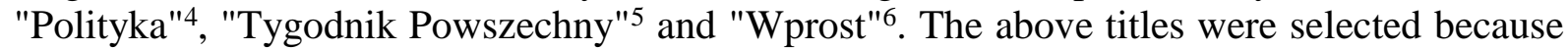
of their large circulations and their prominence as agenda-setting elite weekly magazines. They are read especially among people with at least secondary education, living in cities over 100.000 inhabitants and earning more than 5.000 zlotys per month (Polish readership research, 2019).

It can therefore be assumed that readers of these magazines are representatives of Polish intellectual elite and opinion leaders who, according to the model of a two-step flow of communication (Castillo \& Smolak-Lozano, 2012), have a real impact on the shaping of opinions and attitudes of other people, because they are capable of convincing others to their views. The second reason for the selection of these titles is their diversity in terms of political and ideological bias. It was assumed that this heterogeneity would make it possible to capture possible differences in the ways of portraying disabled people in Polish opinion-forming press.

The basic unit selected for analysis was an article (a reportage, a commentary, a feature article, an essay, an editorial, an interview, a review, etc.) whose content was devoted to issues related to disability and disabled people. In order to observe possible changes, the sample consisted of stories published during two years: September 2012 - August 2013 (the period

\footnotetext{
${ }^{3}$ A socio-political weekly magazine, published as the Polish edition of Newsweek since 2001, of liberal and centrist bias.

${ }^{4}$ An opinion-forming weekly magazine, regularly published since 1957 , currently presenting left-wing and socialdemocratic program line.

${ }^{5}$ A right-wing weekly, published since 1945 for and by representatives of the Catholic intelligentsia in Poland

${ }^{6}$ A socio-political weekly magazine published since 1982, thought to be of a centrist bias.
} 
after the ratification of the Convention on the Rights of Persons with Disabilities) and during the year of 2018. In accordance with the sampling standards used in content analysis (Krippendorff, 2004; Lacy et.al., 2001; Riffe et.al., 1998; Lisowska-Magdziarz, 2004), one issue of each magazine from each month (out of the chosen 24 months) was randomly selected (stratified sampling). Therefore the total number of issues under scrutiny was 96 . The following categories were analysed: subject matter of the article, its placement, the language used, who used particular expressions, the type of social roles in which disabled people were showed.

\section{Conducting research and results}

The total content analysis of 96 issues resulted in 57 articles, either primarily raising the subject of disability or disabled people $(65 \%)$ or devoted to other issues but still in some ways connected to disability (35\%).

\subsection{Characteristics of the sample}

In the period from September 2012 to August 201320 articles were published on the topic, in 2018 this number almost doubled (37 articles). The reason for this change may be linked to political events that took place in April and May 2018 when disabled people and their parents began a 40-day protest in the Polish parliament. The demonstration had a high media coverage and much media attention was devoted to that topic. On the other hand, there were also some interesting events in September 2012, as Poland ratified the Convention on the Rights of Persons with Disabilities and Paralympic Games took place in London, which was widely commented by international media.

Despite this upward trend, the proportion of articles dedicated to disability issues in the chosen magazines was still very low. If we assume that the average number of articles in each issue of "Polityka" is 65, "Newsweek" - 35, "Wprost" - 45 and "Tygodnik Powszechny" - 50, it turns out that there were approximately 4680 articles published during the analysed 24 months. As mentioned above, only 57 articles covered the topics related to disability issues, which is only $1.2 \%$ of the whole sample. However, a slight increase in the percentage of articles related to disability can be noticed - from $0.9 \%$ in $2012 / 2013$ to $1.6 \%$ in 2018 . We may therefore surmise that the topic is slowly becoming interesting for the opinion-forming press, and is appearing more and more frequently in the media discourse, which may result in changes in social perception of disability.

As shown in Table 1, almost half of the analysed articles (47\%) were published in "Polityka". This magazine is a socio-political weekly of social-democratic and left-wing bias, known for promoting equality, social justice and respect for civil rights. Those values and beliefs, unsurprisingly, are strongly related to highlighting social injustice, poverty, and social inequality.

Only 2 out of 57 articles were published in "Tygodnik Powszechny" - a short paragraph describing the meeting of cardinal Kazimierz Nycz with the protesters in the Polish parliament and an interview with Małgorzata Chmielewska, a nun who heads the Bread of Life Community, about the life with her adoptive son with autism. Both of these articles were published in the same issue (20.05.2018), at the culmination of the protest in the Polish parliament. Given the fact that "Tygodnik Powszechny" is a right-wing, socio-cultural, catholic magazine, such a low number of articles on disability issues may be surprising. At the same time, "Newsweek" and "Wprost" have published consecutively 16 and 12 articles dedicated to the topic of disability, which represented $28 \%$ and $21 \%$ of the sample. Both magazines are thought to be centrist. 
However, in order to verify whether the political bias of the magazines had any impact on the frequency of writing about disability, the percentage share of those articles was analysed for each magazine. As shown in the table below, 1.9\% of articles published in "Newsweek" were devoted to disability issues, $1.7 \%$ in "Polityka", $1.1 \%$ in "Wprost" and only $0.2 \%$ in "Tygodnik Powszechny". So, it seems that the topic of disability issues is most frequently discussed in magazines of central and left-wing bias.

Table 1. The number of articles on disability issues in opinion-forming magazines. Different periods of analysis included

\begin{tabular}{|c|c|c|c|c|c|}
\hline Period & „Newsweek” & „Polityka” & $\begin{array}{c}\text { „Tygodnik } \\
\text { Powszechny" }\end{array}$ & „Wprost" & Total \\
\hline $\begin{array}{l}01.09 .2012- \\
31.08 .2013 \\
\end{array}$ & 6 & 9 & 0 & 5 & 20 \\
\hline $\begin{array}{l}01.01 .2018- \\
31.12 .2018 \\
\end{array}$ & 10 & 18 & 2 & 7 & 37 \\
\hline Total & 16 & 27 & 2 & 12 & 57 \\
\hline Percentage & $1.9 \%$ & $1.7 \%$ & $0.2 \%$ & $1.1 \%$ & Average: $1.2 \%$ \\
\hline
\end{tabular}

Source: own research

One of the research questions focused on the topics of articles related to disability issues. The Graph 1 illustrates the variety of the topics discussed in the analysed articles.
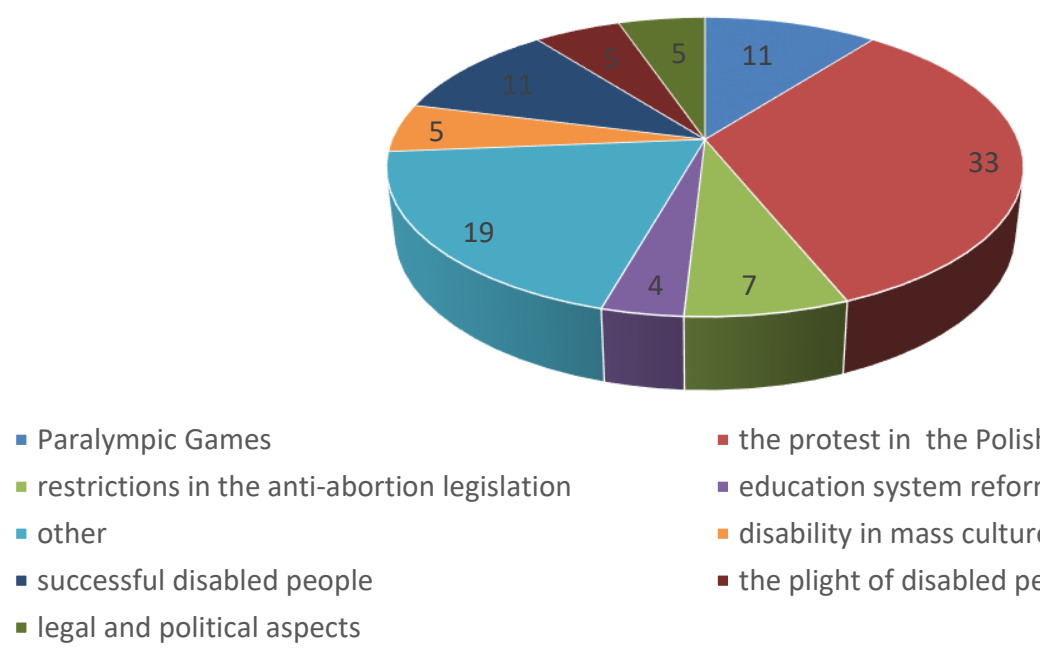

- the protest in the Polish parliament

- education system reform

- disability in mass culture

- the plight of disabled people

Graph 1. Subject matter of articles related to disability issues presented in opinion-forming magazines $(\%)$

Source: own data

The protest held by disabled people and their parents in the Polish parliament in the spring of 2018 was widely reported by media and, in fact, present in one third of the articles (33\%). Other articles on this subject included an editorial on the ruling party's contempt for disabled people and other minority groups; a feature article about a ruling party's "victory" over disabled people protesting in the Polish parliament; an article concerning online hate speech targeted at disabled people with excessive activity of Krystyna Pawłowicz (a Polish MP); an interview with Dorota Próchniewicz, a mother of 23-years old son with a disability, about the 
non-existent health care system; an article about a famous toy monkey from Warsaw uprising or a text concerning first lady's meeting with the protesters.

The achievements of Polish athletes with disabilities during London 2012 Paralympic Games were also a popular topic (11\%). It was presented in e.g. a reportage about difficulties of Polish shot-putter, his struggle to make a living, his training and everyday work; an editorial on heroism of Paralympians and the way Polish society perceive disability and an article in which the journalist notes with astonishment that TVP Polish Television did not broadcast the performances of Polish Paralympians in London.

There were also articles (11\%) which presented disabled people as successful and having achievements. Among these articles there was e.g. a reportage about a girl with a title of Miss Poland Wheelchair; an interview with John Elder Robison, a brilliant engineer and a great writer with Asperger syndrome; a text commemorating the deceased musician, cello virtuoso, and an interview with Bartosz Szpurek, a respected television and radio journalist.

Other topics were related to:

- attempts to restrict the anti-abortion legislation (7\% of the texts), e.g. an article presenting feelings of mothers of children with Down's syndrome and their opinion on the political uproar around the subject of women's right to terminate pregnancy for serious medical reasons,

- disability in mass culture (5\%), e.g. an article on commercial brands and advertising agencies that involve disabled people to promote their products,

- problems related to disability (5\%), e.g. a reportage about returning to sexual fitness by people with severe spinal injuries,

- legal and political aspects (5\%), e.g. article on "Accessibility+" - government's program focused on adapting public spaces, architecture, transport and products to the needs of disabled people,

- education reform (4\%), e.g. text presenting difficulties with placing a child with disabilities in a public school.

Almost one-fifth of all the analysed texts (19\%) was categorised by researchers as "other topics", as because of their diversity they were difficult to classify.

The importance of the topic is also demonstrated by its placement. It was therefore examined how often the subject of disability and disabled people was a cover story and how much space it took. Out of the 96 analysed issues, stories related to disability appeared on the front covers only 3 times, thus it may be concluded that disability is not a leading topic for opinion-forming magazines. In addition, two of these covers were related to the topics of suffering, difficulties and caregiver's sacrifice, the third one - a heroic Paralympian. Undoubtedly, it has a considerable influence on the image of disabled people presented in the media.

The dominating genre of the articles were reportages and interviews, long text forms that capture readers' attention. In terms of placement, the analysed articles were mostly located in the "society" section. It seems worth noting that the articles were most frequently written by women. In "Newsweek" such topics were mostly dealt with by Małgorzata Święchowicz, in "Wprost" by Magda Papuzinska, and in "Polityka" by Agnieszka Sowa, Dorota Szwarcman, Joanna Cieśla and Martyna Bunda.

\subsection{Phrases used for describing disability}

One of the main purposes of the study was to verify whether the phrase osoba $z$ niepetnosprawnościa is used in the opinion-forming press and what kind of other expressions are in use while referring to disabled people. We concentrated on the following three terms: 
- osoba z niepetnosprawnościa (person with a disability)

- osoba niepetnosprawna (a disabled person)

- niepetnosprawny (disabled, a noun)

The Table 2 shows the frequency of using the above mentioned terms, according to the analysed period of time. In the first period (2012/13) there was a clear dominance of the terms osoba niepetnosprawna (14 articles) and niepetnosprawny (13 articles). It seems surprising that the term osoba z niepetnosprawnościa was not used at all. In the year of 2018 this term was used 17 times, however, the expressions osoba niepetnosprawna i niepetnosprawny were still used more frequently.

Table 2. Expressions denoting disabled people used in Polish opinion-forming magazines. Different periods of analysis included

\begin{tabular}{cccc}
\hline \multicolumn{3}{c}{ Term } \\
\hline Period & $\begin{array}{c}\text { osobaz } \\
\text { niepetnosprawnościa }\end{array}$ & osoba niepetnosprawna & niepetnosprawny \\
\hline $\mathbf{0 1 . 0 9 . 2 0 1 2 -}$ & 0 & 14 & 13 \\
$\mathbf{3 1 . 0 8 . 2 0 1 3}$ & & 31 & 26 \\
\hline $\mathbf{0 1 . 0 1 . 2 0 1 8}$ & 17 & & \\
\hline $\mathbf{3 1 . 1 2 . 2 0 1 8}$ & & & \\
\hline
\end{tabular}

Source: own data

If we look at the frequency of the use of the term osoba $z$ niepelnosprawnościa by the analysed magazines, it can be noticed that this expression appeared most often in "Polityka" (11 articles/27 with the examples of the above mentioned expressions). The rest of the selected magazines used that term occasionally ("Wprost" 3/12, "Newsweek" 3/10) or not at all (“Tygodnik Powszechny").

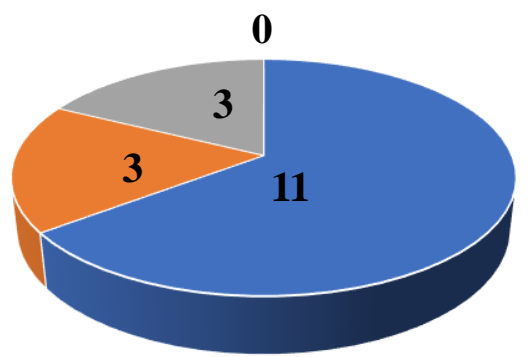

$$
\text { - "Polityka" - "Newsweek" - "Wprost" - "Tygodnik Powszechny" }
$$

Graph 2. The articles with the term osoba z niepetnosprawnościa in 2018

Source: own data

There was a noticeable inconsistency in the use of the term osoba $z$ niepetnosprawnościa. It seems that the journalists used this phrase rather as a synonym, a substitute, in order to add variety to the text. It should be noted that journalists were not the only people referring to disability issues, there were also comments made by disabled people themselves, their family members, experts. Surprisingly, the term osoba z niepetnosprawnościa was never used by a disabled person. Dr. Sylwia Spurek, Deputy Commissioner for Human Rights for Equal Treatment in Poland, was the only expert who used this expression consistently. Małgorzata Święchowicz "Newsweek" journalist, used this expression in her texts most often. In the article "Dzieci jak domki z kart" (Children like houses of cards), describing issues concerning education system for children with disabilities, she used the term 
niepetnosprawny only once, and several dozen times osoba $z$ niepetnosprawnościa, which clearly indicates the intentional and sensitive use of disability language by the journalist.

The phrase osoba niepetnosprawna was used not only by journalists, but also by disabled people, experts, quoted politicians and Internet users. It is worth noting that most of the experts who are involved in disability issues used all the three above mentioned terms interchangeably (e.g. an employee of the Institute of Social Policy of the University of Warsaw, president of Polish Sports Association for the Disabled, or a representative of Helen Keller Foundation). The expression niepetnosprawny was most often used by journalists and relatives of disabled people, the least frequently by disabled people themselves.

Although it was not the purpose of this study, it drew our attention that many names of public institutions and NGOs contain the expressions osoba niepetnosprawna and niepetnosprawny, e.g. "The State Fund for Rehabilitation of Disabled Persons", "The Office of the Government Plenipotentiary for Disabled People", "Polish Organization of Employers of Disabled People", "Polish Sports Association for the Disabled", "Foundation of Active Disabled" or "Disabled People Forum". The issues of the expressions used in the names of public institutions and NGOs are worth exploring further.

Apart from the presence of the terms mentioned above, we also tried to analyse other expressions used to describe disabled people. It can be found that there are still examples of stigmatising language, such as:

- noun phrases: kaleka (cripple), inwalida (an invalid), autystyk (an autistic),

- prepositional phrases: osoba z ułomnościami (a person with deficiencies), osoba $z$ dysfunkcjami (a person with dysfunctions), osoba z deficytami (a person with deficits),

- adjectival phrases: (ciężko/głęboko) upośledzony (severely/deeply impaired), ślepy (blind), kaleki (crippled), ułomny (lame),

- loaded phrases: dotknięty autyzmem (affected by autism), obarczony schizofrenia (fraught with schizophrenia), cierpiacy na porażenie mózgowe (suffering from cerebral palsy), przykuty do wózka (wheelchair-bound), pokrzywdzony przez los (disadvantaged).

However, there is a visible decrease in the number of articles in which the abovementioned words and phrases appeared - in the first analyzed period (2012/13) they could be found in 11 articles (out of 20 texts containing terms related to disabled people other than osoba z niepetnosprawnościa/osoba niepetnosprawna/niepetnosprawny), in 2018 only in 6 articles out of 23. Sensitivity in the choice of words may be seen in the statement of a journalist interviewing Monika Kuszyńska, a singer who has become a wheelchair user after an accident: "I'm a bit scared, I don't know how to choose words so as not to involuntarily say something awkward." Interestingly, disabled people and their relatives also use terms considered stigmatizing: debil (a moron), imbecyl (an imbecile), kaleka (a cripple), głęboko upośledzony (deeply retarded), opóźnienie umysłowe (mental retardation), autystyk (an autistic).

A separate topic for analysis is the text of Jan Hartman, a well-known Polish philosopher, "Władza i kalectwo" (Power and disability), which is entirely devoted to disability language. The first half of the text is an analysis of the terms used to refer to disabled people. The author criticizes "pioneers of Polish political correctness", talks about "opportunism of public language creators", "mockery" and "hypocrisy." He ironically speaks of American fashion ("lexical panic") for "all these "expressions with disabilities'", and separating disabilities from human identities. He refers to it as "linguistic hocus-pocus". He criticizes the term niepetnosprawny (disabled): "this word lies with all its semantics: but you are fit, as much as you can, but not entirely". The author promotes the use of the word inwalida (an invalid): "there is more courage and respect in this foreign and elegant word. I urge everyone to return to this wise invention". 
The subject of disability language was also taken up by Tomasz Lis, editor-in-chief of "Newsweek", in his editorial written directly after the London 2012 Paralympic Games. Appealing for a community in which "there are no cripples, there are only physically disabled. There are no abnormal people. There are at most mentally disabled", he calls for the exchange of some pejorative terms (cripples, abnormal) for hardly more positive (noun phrases: physically/ mentally disabled). He also uses the term fizyczne ułomności (physical disabilities).

\subsection{Social roles played by disabled people}

The issue of social roles in which disabled people are presented was also analyzed to verify whether along with the language change there has been also any change in the way disabled people are portrayed. As it turns out, in both analyzed periods disabled people who are subjects of the texts have been shown in a wide variety of social roles. Such diversity allows to avoid tearing out disabled people from their social context and showing them in onedimensional way only as patients or residents of care homes (Ruść, 2007). It is difficult to notice any clear evolution in presenting the social roles of disabled people. It can be clearly seen, however, that the roles presented depend on the analyzed period and the dominant topics of the articles at that time. In the first of the analyzed periods, due to the interest in the London 2012 Paralympic Games, in 1/3 of the articles disabled people were portrayed as athletes, while in the second analyzed period, 2018, in almost half of the articles they were showed as protesters and fighters for their rights. Disabled people were also presented as family members, partners, employees, pupils, students, creators. There were also individual cases of disabled people acting as a journalist, a model, a convict, a trainer, a volunteer and a clerk. On the other hand, you can also find ways of "traditional" way of presenting disabled people as patients ( $1 / 3$ of the texts in 2012) and people in need of support (mainly in 2018, which is associated with presenting the protest od disabled people and their parents).

Table 3. Social roles played by disabled people in the analysed articles

\begin{tabular}{lcc}
\hline Presented social roles & \multicolumn{2}{c}{ Number of articles } \\
\cline { 2 - 3 } & $09.2012-$ & $01.2018-$ \\
\hline patient & 08.2013 & 12.2018 \\
\hline family member (child, sister, brother, parents) & 7 & 3 \\
\hline athlete & 6 & 13 \\
\hline partner, spouse & 6 & 1 \\
\hline employee & 4 & 1 \\
\hline student & 4 & 2 \\
\hline protester & 3 & 4 \\
\hline aid beneficiary, person in need of support & 0 & 17 \\
\hline creator (writer, scientist, inventor, singer, musician, scientist, & 1 & 3 \\
game creator, actor) & 2 & 37 \\
\hline Total numer of articles & & \\
\hline
\end{tabular}

Source: own data

It is worth noting that all the texts in which the main character is a disabled person depict them as active and successful, without too much focus on their disabilities, but also without making them "superheroes" (the texts were classified above as the ones presenting successful people). 
Nevertheless, in the analyzed articles you can still find those in which the representation of disabled people corresponds to the two most popular models - a "super cripple" or a model of social pathology. The first of these models can be seen in three texts, all from 2012, which focused on the athletes with disabilities, especially Paralympians. They described "competition which took a superhuman effort" and presented Oscar Pistorius as "living proof of the victory of the spirit over the body, encouragement for thousands of disabled people; a real hero".

The aforementioned editorial of Tomasz Lis adopts a similar tone. His goal was undoubtedly to appeal for acceptance of disabled people, but despite the title ("One of us") he portrays disabled people as "tragic heroes", "superhumans", "not victims but tough guys, not incapable of what is the norm, but capable of extraordinary things that are beyond the norm". In addition, the text focuses on people with physical disabilities, ignoring the situation of people with other types of disabilities.

Among the analyzed articles were also those that corresponded to the social pathology model. The text "People from the abyss" comes to the fore here, creating the image of disabled people as people whose "life is a nightmare", living in the abyss of "misery and hopelessness" under the "able-bodied top", where there is an ongoing "fight for surviving the next day". According to the author, during the protest of disabled people and their parents in the Polish parliament there was "a real festival of knowledge about disabled people" in the media. However, it turns out that the media concentrated on "hundreds of stories about misery, sadness, fatigue, loneliness and fear". Reporting on the protest in the parliament, the focus was on showing "completely vulnerable, needy (...) people whose only weapon is suffering", those who are "unwanted, unnoticed, excluded".

\section{Conclusion}

The article presents the evolution of language and expressions used to describe the topic of disability and disabled people in the Polish opinion-forming press. The analysis encompassed the texts published in weekly magazines "Newsweek", "Polityka", "Wprost" and "Tygodnik Powszechny" during two years. The sample was analysed with the use of content media analysis method. The results of the analysis allowed us to answer the research questions and verify the hypotheses.

As it was noticed, the topic of disability and disabled people appears in Polish opinionforming press extremely rarely - only in $1.2 \%$ of all articles published in the analysed period. However, as it was observed, the frequency of the use of this expression has increased gradually over time. It should be pointed out that articles on such issues are published more often in the magazines of a left-wing and centrist bias. There was a noticeable impact of the current political and social events on the frequency of writing about disability. For instance, the number of articles significantly increased due to the London 2012 Paralympic Games or the protest in the Polish parliament organised by disabled people and their parents. Among 57 articles, more than a half $(52 \%)$ dealt with the matters mentioned above. Despite that, only 3 articles out of 96 made the covers. It may demonstrate the low appreciation of disability issues by the opinionforming press.

Over the analysed period of five years, the phrase osoba z niepetnosprawnościa has become a part of the media discourse and is more often used by journalists, although in most cases it seems to be an unintentional practice. This expression was most frequently used in "Polityka", while other magazines used it occasionally ("Wprost", "Newsweek") or not at all ("Tygodnik Powszechny"). Nevertheless, the most common phrases used by these magazines were osoba niepetnosprawna and niepetnosprawny. As for the language used by journalists to describe disability and people with disabilities, in both analyzed periods examples of 
stigmatizing language can be found, although there is a visible decrease in the number of articles in which such expressions appeared.

Disabled people described in the articles were presented in a wide variety of social roles. However, it is difficult to notice any clear evolution in presenting the social roles of disabled people. Both in the period 2012/2013 and in 2018, the articles published presented disabled people as passive as well as active in professional and social life. This fact leads to the conclusion that a slow change in terminology used by the media ('change of label'), has had no significant influence on the presentation of the social roles performed by disabled people.

The findings presented here provide a starting point for further investigation of disability language used in the media. Moreover, this study raises a number of questions concerning the issue of disability identity and the language preferred by disabled people themselves, which offers opportunities for further research.

\section{References}

Bąba, W. (2015). Analiza $i$ ocena polskiego systemu zatrudnienia osób z niepetnosprawnościami. Kraków: Wydawnictwo Uniwersytetu Ekonomicznego 2015.

Barnes, C. (1992). Disabling Imagery and the Media. An Exploration of the Principles for Media Representations of Disabled People. The First in a Series of Reports. Halifax: Ryburn Publishing.

Białek, I. (2006). Wywiad z prof. Jerzym Bralczykiem. Retrieved September 19, 2019, from http://www.dare.home.pl/idol/pl/obral.php

Brzezińska, A., Woźniak, Z., \& Maj, K. (Eds.). (2007). Osoby z ograniczona sprawnościa na rynku pracy. Warszawa: Wyd. SWPS „Academica”.

Castillo, E. A., \& Smolak-Lozano, E. (2012). Historyczny rozwój koncepcji teoretycznych na temat roli środków masowego przekazu w społeczeństwie. Lingua ac Communitas, Vol. $22,2012,181-203$.

Clark, L., \& Marsh, S. (2002). Patriarchy in the UK: The Language of Disability. Retrieved September 19, 2019, from https://disability-studies.leeds.ac.uk/wpcontent/uploads/sites/40/library/Clark-Laurence-language.pdf

Clogston, J.S. (1990). Disability coverage in 16 newspapers. Louisville, KY: Avocado Press.

Dycht, M., \& Marszałek, L. (2009). Inkluzja i ekskluzja społeczna osób z niepetna sprawnością: współczesne konteksty $i$ kontrowersje pedagogiki wspierajacej. Warszawa: Wydawnictwo Salezjańskie.

Fiedorowicz, M. (2016). Raport dotyczacy wdrażania art. 8 konwencji o prawach osób niepetnosprawnych $w$ Polsce. Podnoszenie świadomości. Retrieved September 19, 2019, from https://www.dzp.pl/files/shares/Publikacje/Raport_tematyczny_art.8.pdf

Finkelstein, V. (1980). Attitudes and disabled people. New York: World Rehabilitation Fund.

Finkelstein, V. (1981). To deny or not to deny disability. In A. Brechin,. et al. (Eds.) Handicap in a Social World. Sevenoaks: Hodder and Stoughton.

Franczak, M. (2011). Edukacja i aktywizacja zawodowa osób z niepetnosprawnościami. Wałbrzych : Wydawnictwo Państwowej Wyższej Szkoły Zawodowej im. Angelusa.

Galasiński, D. (2013). Osoby niepełnosprawne czy z niepełnosprawnością? Niepetnosprawność - zagadnienia, problemy, rozwiazania, nr IV(9), 3-6.

Garbat, M. (2015). Historia niepetnosprawności: geneza i rozwój rehabilitacji, pomocy technicznych oraz wsparcia dla osób z niepetnosprawnościami. Gdynia: Novae Res Wydawnictwo Innowacyjne. 
Giannantonio, C. M. (2010). Book Review: Krippendorff, K. (2004). Content Analysis: An Introduction to Its Methodology (2nd ed.). Thousand Oaks, CA: Sage. Organizational Research Methods, 13(2), 392-394. https://doi.org/10.1177/1094428108324513

Goban-Klas, T. (2008). Media i komunikowanie masowe. Teorie i analizy prasy, radia, telewizji i Internetu. Warszawa: Wydawnictwo Naukowe.

Goldman, J., \& Wojtaś J. (2015). Społeczne i medyczne konteksty funkcjonowania osób z niepetnosprawnościami. Legnica: Wydawnictwo Państwowej Wyższej Szkoły Zawodowej im. Witelona.

Haller, B. (1999). How the News Frames Disability: Print Media Coverage of the Americans with Disabilities Act. Research in Social Science and Disability, Vol. 1. New York: JAI Press.

Inimah, G.M., Mukulu, E., \& Mathooko, P. (2012). Literature Review on Media Portrayal of People with Disabilities in Kenya. International Journal of Humanities and Social Science, 2 (8).

Janocha, W. (2008). Poczucie sensu życia osób z niepetnosprawnością. Kielce: Wydawnictwo Jedność.

Kaczmarska, B. (2017). Twórczość artystyczna w życiu osób z niepełnosprawnością indywidualny i społeczny wymiar arteterapii. Niepetnosprawność - zagadnienia, problemy, rozwiazania, $\mathrm{Nr} \mathrm{I} / 2017(22)$ 1, 107-129.

Katz, E., \& Lazarsfeld, P. (1955). Personal influence: the part played by people in the flow of mass communications. New York: Free Press.

Katz, E. (1957). The Two-Step Flow of Communication: An Up-To-Date Report on an Hypothesis. Public Opinion Quarterly, 21(1), Anniversary Issue Devoted to Twenty Years of Public Opinion Research), 61. doi:10.1086/266687

Klapper, J. T. (1957). What We Know About the Effects of Mass Communication: The Brink of Hope. Public Opinion Quarterly, 21(4), 453. doi:10.1086/266744

Korombel, A. (2018). Osoby z niepetnosprawnościami - petne uczestnictwo w społeczeństwie: podnoszenie jakości życia osób z niepetnosprawnościami $w$ Polsce. Częstochowa: Wydawnictwo Wydziału Zarządzania Politechniki Częstochowskiej.

Krippendorff, K. (2004). Content Analysis: An Introduction to Its Methodology (2nd ed.) Thousand Oaks, CA: Sage Publications.

Kubicki, P. (2017). Polityka publiczna wobec osób z niepetnosprawnościami. Warszawa: Oficyna Wydawnicza SGH.

Kurowski, K. (2014). Wolności $i$ prawa człowieka $i$ obywatela $z$ perspektywy osób $z$ niepetnosprawnościami. Warszawa: Biuro Rzecznika Praw Obywatelskich.

Lacy, S., Riffe, D., Stoddard, S., Martin, H., \& Chang, K.-K. (2001). Sample Size for Newspaper Content Analysis in Multi-Year Studies. Journalism \& Mass Communication Quarterly, 78(4), 836-845. doi:10.1177/107769900107800414

Lazarsfeld, P., Berelson, B., \& Gaudet H. (1948). The people's choice: how the voter makes up his mind in a presidential campaign. New York: Columbia University Press.

Lisowska-Magdziarz, M. (2004). Analiza zawartości mediów. Przewodnik dla studentów. Kraków: Wydawnictwo Uniwersytetu Jagiellońskiego.

Lawson, J. (2001). Disability as a Cultural Identity, International Studies in Sociology of Education, 11 (3), 203-222. doi: 10.1080/0962021010020007.

Mikołajczyk, B. (2012). Międzynarodowa ochrona praw osób starszych. Warszawa: Wolters Kluwer Business.

McQuail, D. (2010). McQuail's mass communication theory. London: Sage Publications.

Niedbalski, J. (2015). Sport osób niepetnosprawnych $w$ przekazie $i$ dyskursie medialnym $w$ Polsce. Przegląd Socjologii Jakościowej, t. 11, nr 2, 130-159. 
Oliver, M. (1990). The politics of disablement. Basingstoke: Macmillan.

Oliver, M. (1996). Understanding disability: from theory to practice. Basingstoke: Macmillan.

Paszkowicz, M.A., Garbat, M. (2013). Osoby z niepelnosprawnościami w polityce społecznej $=$ People with disabilities in the social policy. T. 1. Zielona Góra: Polskie Towarzystwo Ekonomiczne.

Pawlas-Czyż, S. (2012). Profesjonalna praca socjalna z rodzinami osób z niepełną sprawnością. Praca Socjalna. R. 27, nr 3, 40-59.

Polish readership research (2019). Retrieved September 19, 2019, from https://www.pbc.pl/rynek-prasowy/ 2019.

Riffe, D.; Lacy, S., \& Fico, F. G. (1998). Analyzing media messages: Using quantitative content analysis in research. Mahwah, NJ: Lawrence Erlbaum.

Rozmus, P. (2012). Odmienność odbita w ekranach. Konstruowanie obrazu niepełnosprawności poprzez kampanie społeczne i telewizję. Palimpsest, nr 2, 103-118.

Ruść, I. (2007). Wizerunek osób z ograniczona sprawnościa w mediach, Anna Brzezińska\& Zbigniew Woźniak \& Konrad Maj (Eds.)., Osoby z ograniczona sprawnościa na rynku pracy (s. 131-148). Warszawa: Wyd. SWPS „Academica”.

Rutkowska, E. (2007). Pracownik z niepetnosprawnościa. Lublin: Norbertinum Wydawnictwo - Drukarnia - Księgarnia.

Rymsza, M. (2016). Niepetnosprawny jako aktywny obywatel- problematyka integracji społecznej $i$ zawodowej osób niepetnosprawnych $w$ Polsce. Elżbieta ZakrzewskaManterys \& Jakub Niedbalski (Eds.) Samodzielni, zaradni, niezależni. Ludzie niepetnosprawni w systemie polityki, pracy i edukacji (13-46). Łódź: Wyd. Uniwersytetu Łódzkiego.

Rzecznik Praw Obywatelskich. (2012). Zasada równego traktowania. Prawo i praktyka, nr 3, Równe szanse w dostępie do edukacji osób z niepełnosprawnościami. Analiza i zalecenia. Warszawa.

Rzecznik Praw Obywatelskich. (2015). Zasada równego traktowania - prawo i praktyka, nr 16. Dostępność edukacji akademickiej dla osób z niepełnosprawnościami. Warszawa.

Shakespeare, T., Watson, N. (2001). The social model of disability: an outdated ideology? In S. Barnarrt, \& B.M. Altman (Eds.), Exploring Theories and Expanding Methodologies: where are we and where do we need to go? Research in Social Science and Disability volume 2. Amsterdam: JAI.

Sieradzki, M. (1997). Niepełnosprawność i ideologia. Problemy rehabilitacji społecznej $i$ zawodowej, 3(153), 67-69.

Simonson, P. (2012). The Rise and Fall of the Limited Effects Model. The International Encyclopedia of Media Studies. doi:10.1002/9781444361506.wbiems03

Sproule, J. M. (1987). Propaganda studies in American social science: The rise and fall of the critical paradigm. Quarterly Journal of Speech, 73(1), 60-78. doi:10.1080/00335638709383794

Struck-Peregończyk, M., \& Kurek-Ochmańska, O. (2018). Wizerunek osób niepełnosprawnych w polskiej prasie opiniotwórczej na przykładzie tygodnika „Polityka” w latach 19972016. Przeglad Socjologii Jakościowej, XIV(3), 48-71. doi: https://doi.org/10.18778/1733-8069.14.3.04

Struck-Peregończyk, M., \& Leonowicz-Bukała I. (2018). Bezbronne ofiary czy dzielni bohaterowie: wizerunek osób niepełnosprawnych w polskiej prasie. Studia de Cultura. Annales Universitatis Paedagogicae Cracoviensis, 10(1), 148-164. doi: $10.24917 / 20837275.10 .1 .12$ 
Sztobryn-Giercuszkiewicz, J. (2018). Szanse i ograniczenia ksztatcenia akademickiego osób z niepetnosprawnościami $w$ Polsce: perspektywa socjologiczna. Łódź: Wydawnictwo Politechniki Łódzkiej.

Tomczyszyn, D., \& Romanowicz, W. (2012). Aktywność zawodowa osób z niepetnosprawnością. Biała Podlaska: Wydawnictwo PSW im. Papieża Jana Pawła II. 